\title{
PHYTOPOPULATION BASES OF FOREST PHYTOCENOES SUSTAINABILITY OF THE UKRAINIAN POLESIE
}

\author{
Kovalenko I. N.
}

\section{INTRODUCTION}

Ukrainian Polesie occupies a significant part of the Polesye lowland and differs from other Ukrainian regions in well-preserved forests. The total forest cover of the Ukrainian Polesye territory is 26-29\%. Pine, pine-oak, oak-hornbeam and birch forests predominate ${ }^{1}$. These are phytocenoses of classes Br.-Bl. et Vlieger in Vlieger 1937, Vaccinio-Piceetea Br.-Bl. in Braun-Blanquet, Sissingh et Vlieger 1939 and Pulsatillo-Pinetea Oberdorfer 1992. There is a tendency for the expansion of birch distribution (Betula pendula Roth) due to the ability to efficient natural regeneration and rapid growth in the region ${ }^{2}$.

The Ukrainian Polesie forests are of great sozological and economic value. The region vegetation cover has been well studied and described in many articles and monographs ${ }^{3}$.

\section{Characteristics of forest phytocenoses of Ukrainian Polesie}

Degradation and destruction of forest vegetation is a global problem. In the last 20-30 years alone, the average forest cover on the planet has decreased from 29 to $27 \%$, the stock of timber - from 360 to 336 billion cubic meters ${ }^{4}$. This problem also touched upon the Ukrainian Polesie. For the period 2011-2018, the area of deforested forests amounted to $1100 \mathrm{~km}^{2}$ in the Zhytomyr region, $763 \mathrm{~km}^{2}$ in Rivne, $388 \mathrm{~km}^{2}$ in Chernigov and $153 \mathrm{~km}^{2}$ in Sumy.

For Ukraine, the forest phytocenoses significance of Polesye is extremely great. They play a water protection role, stabilize the climate, prevent soil

\footnotetext{
Андрієнко Т.Л. Рослинність Українського Полісся. Фіторізноманіття Украӥнського Полісся та його охорона. Київ, 2006. С. 13-37.

2 Сірук Ю.В.,. Печенюк Є.П, Чернюк Т.М. Типологічна структура та характеристика лісового фонду центрального Полісся України. Науковий вісник НЛТУ Украӥни. 2015. Вип. 25.10. С. 97-103.

3 Брадіс Є.М., Андрієнко Т.Л. Детальне геоботанічне районування Полісся УРСР. Украӥнський ботанічний журнал. 1975. Т. 32. № 4. С. 471-475.

${ }^{4}$ Состояние лесов мира - 2020. Леса, биоразнообразие, люди. Рим : ФAO. URL: https://doi.org/10.4060/ca8642ru.
} 
degradation, and ensure the absorption and preservation of carbon in the atmosphere.

Several biosphere and natural parks have been organized in order to protect forests on the territory of the Ukrainian Polesie ${ }^{5}$. Nevertheless, the Ukrainian Polesye forests, even those located in protected areas, are influenced by a variety of negative natural and anthropogenic factors. These are global climate change, including, first of all, the temperature regime and the amount of precipitation, air pollution by industrial emissions, deep anthropogenic transformations of the territories adjacent to forests, changes in the composition of the fauna, etc.

Therefore, an urgent scientific problem is the stability assessment of forest phytocenoses of the Ukrainian Polesie and factors that affect the level of forest resistance to a complex of external adverse influences.

The sustainability of natural ecosystems in ecology is defined as follows: "The environmental sustainability is a property of highly organized systems for maintaining, within certain limits, the values of the main parameters of their state in an unstable environment, achieved by effectively extinguishing external disturbing effects in internal circuits due to various adaptations and the presence of feedbacks between all elements, developed in the process of long evolution of living matter and aimed at its successful continuation" ${ }^{6}$. In silvicultural literature, the stability of forest ecosystems is usually understood as their ability to maintain structure, productivity, and functional qualities under adverse external influences ${ }^{7}$.

A stable forest phytocenosis for a sufficiently long time retains the species composition, a certain quantitative ratio between different plant species, their distribution over ecological niches and the ability to self-sustain due to the reproductive process of its entire structure-forming plant species.

The sustainability of forest communities depends on various factors. This is, first of all, the correspondence of the ecological amplitudes of plant species that are included in a given phytocenosis to the main ecological modes of habitat. Climatic parameters and soil properties are at the first place. Of great importance in the formation of the stability of phytocenoses is its so-called phytocenotic isolation, i.e. the ability to preserve the species composition and structure, to resist the introduction of alien species. It is associated with the absence of

5 Лукаш А.В., Андриенко Т.Л. Созологически ценные растительные сообщества Полесья. Чернигов, 2014. 160 с.

6 Демаков Ю.П. Диагностика устойчивости лесных экосистем: методологические и методические аспекты. Йошкар-Ола, 2000. 416 с.

7 Бех И.А., Данченко А.М. Проблема устойчивости в лесоведении. Вестник Томского государственного университета. 2007. № 295 С. 215-219. 
"empty ecological niches" in a stable phytocenosis ${ }^{8}$. This aspect of the problem is now becoming more and more relevant, since 322 adventive plant species have been registered in Polesie, a large part of which are invasive transformers that destroy natural forest phytocenoses ${ }^{9}$.

Biological invasions are currently regarded as one of the main threats to biodiversity and the sustainability of natural ecosystems. The introduction of invasive species also occurs in protected natural forests. Thus, in the Desnyansko-Starogutsky National Natural Park, 126 invasive species were registered, and their share in the flora is $16 \%{ }^{10}$. The flora of this park contains invasive ephemerophytes Callistephus chinensis (L.) Nees, Nicotiana rustica L., Lupinus luteus L., Aronia melanocarpa (Michx.) Elliot, and xenophytes Epilobium pseudorubescens A. K. Skvortsov and Axyris amaranthoides L.

The main factors of a decrease or complete violation of the typical natural forest phytocenoses stability in conditions of the Ukrainian Polesie are:

a) climatic anomalies, including pronounced changes in temperature and precipitation,

b) changes in the edaphic regime, primarily a change in the level of standing of groundwater,

b) hurricanes causing windfalls,

c) natural forest fires,

d) outbreaks of forest pests and fungal or bacterial plant diseases.

In the forestry, the factors that negatively affect forest ecosystems are specially identified. These include not only natural, but also anthropogenic influences, such as air pollution by industrial emissions of harmful substances, pollution of the environment with agricultural waste, grazing animals from the forest, active recreation, and others. The role of these factors is growing dynamically, since the economy of the Ukrainian Polesie has been developing very rapidly in recent decades ${ }^{11}$.

\footnotetext{
8 Реймерс Н.Ф. Экология (теории, законы, правила, принципы и гипотезы). Москва : Россия Молодая, 1994. 367 с

${ }^{9}$ Стойко С.М. Основи фітосозології та ії̈ завдання у збереженні фітогенофонду і фітоценофонду. Украӥнський ботанічний журнал. 2011. Т. 68. № 3. С. 331-351.

10 Панченко С.М., Кутявін Є.Г. Гербарій Національного природного парку «Деснянсько-Старогутський». Суми : Унів. книга, 2011. 82 с.

11 Природообустройство Полесья : монография / под общ. науч. ред. Ю.А. Мажайского и др. Рязань : Мещер. ф-л ВНИИГиМ им. А.Н. Костякова, 2018. Кн. 2. Т. 2. 804 c.
} 
An important factor in the sustainability of forests is the success of the renewal process of forest-forming tree species, as well as other plant species, which are structure-forming agents of different layers of the phytocenosis ${ }^{12}$.

Based on the analysis of the forest phytocenoses state in the Ukrainian Polesie, it can be concluded that their stability to a certain extent depends on the level of biodiversity. There is a correlation between the resistance of the phytocenosis and its species diversity. In particular, this was demonstrated on a large group of vegetatively mobile plants of the herb-subshrub layer of the forest communities ${ }^{13}$.

In this case, not only the species diversity itself is important, but also the diversity of life forms and ecological properties of all plant species that form this forest phytocenosis. Even more important for the sustainable existence of a forest community is its formation by historically developed coadaptive complexes ${ }^{14}$.

Recognizing a certain relationship between species biodiversity and the stability of phytocenoses, a number of authors cited facts indicating that this relationship is of a more complex nature ${ }^{15}$. In fact, it is not the species diversity as such that is of primary importance, but the state of phytopopulations that form the forest phytocenosis and especially the state of populations of the herb-dwarf shrub layer, since it is associated with the presence of renewal niches for tree species and the possibility of forming a viable undergrowth.

Indeed, from the point of view of sustainable functioning in the forest communities, the most important layer is the herb-dwarf shrub layer. The biodiversity level of the forest phytocenosis is associated with it. In lowland forests, the diversity of tree species is determined on average in 20 species, and in the herb-dwarf shrub layer - in 400 species of plants ${ }^{16}$. This tier contains reforestation niches of tree forest-forming species. It is in this layer

12 Скляр В.Г. Ценотичні зв'зки підросту клена гостролистного та дуба звичайного в умовах Новгород-Сіверського Полісся. Біологічний вісник МДПУ. 2012. № 3. C. 77-88.

${ }^{13}$ Коваленко И.Н. Биоразнообразие растений нижних ярусов лесных экосистем как предпосылка их устойчивости. Вестник КГУ им. Некрасова. 2014. № 4. С. 41-44.

${ }^{14}$ Вахрушев А.А., Раутиан А.С. Исторический подход в экологии: сущность и перспективы. Биологическое разнообразие: подходы к изучению и сохранению : мат. конф. БИН РАН и ЗИН РАН. 1992. С. 14-15.

15 Дыренков С.А. Структура и динамика таежных ельников. Львов : Наука, 1984. 174 с

16 Романовский М.Г., Тарханов С.Н., Щекалев Р.В. Подходы к описанию биоразнообразия равнинных лесов Европейской России. Лесной журнал. 2009. № 4. C. $47-56$. 
that the mechanisms of the formation of stable phytocenotic structures synusia, microgroups, and cenocells ${ }^{17}$.

Based on theoretical considerations and literature data, it has been established that the coenotic parameters underlying the natural stability of forest phytocenoses at the level of the phytopopulations forming them are:

a) a sufficiently high level of viability of structure-forming plants of the herb-dwarf shrub layer and undergrowth of forest-forming tree species, assessed by their vitality,

b) the reproductive potential of the main plant species that form the forest phytocenosis,

c) the completeness of ontogenetic spectra of plants of a phytocenosis, as an indicator of the optimality of the ecological-cenotic situation in a phytocenosis for all structure-forming plants of a given community,

d) the structure of cenocells as elementary cenotic structures of the forest community as an indicator of the level of coadaptation of plants to joint growth.

The considered parameters significance of the forest phytocenoses stability is considered on the example of five forest associations characteristic of the Ukrainian Polesie. These associations were identified on the basis of complete geobotanical descriptions, taking into account modern syntaxonomic solutions ${ }^{18}$.

1. Acc. Mercuriali perrenis-Quercetum roboris Bulokhov et Solomeshch 2003. Broadleaf mesotrophic nemoral forests from Quercus robur with Acer plananoides and Tilia cordata. Typical for wetlands and sandy river terraces. Soils are sod-slightly podzolic or sandy loam, light loamy ${ }^{19}$.

2. Acc. Querco robori-Pinetum (W. Matuszkiewicz 1981) J. Matuszkiewicz 1988. Mixed oak-pine forests. Placed on sandy loamy sodpodzolic soils. In the grass-dwarf shrub layer, small undergrowth of both forest-forming tree species is rather abundant.

3. Acc. Molinio-Pinetum W. Matuszkiewicz et J. Matuszkiewicz (1973) 1983. Wet and moist pine forests. The projective cover of the grass-dwarf shrub layer is on average about $40 \%$. The presence of moisture-loving plant species is characteristic.

4. Acc. Peucedano-Pinetum W. Matuszkiewicz (1962) 1973. Pine forests with well-developed grass and moss cover. The stand usually includes

${ }^{17}$ Weiher E., Keddy P. Assembly rules as general constraints on community composition. Ecological assembly rules: perspectives, advances, retreats. 2004. P. 251-271.

${ }_{18}$ Matuszkiewicz W. Przewodnik do oznaczania zbiorowisk roślinnych Polski. Warczawa, 2001. 537 p.

19 Булохов А.Д., Соломещ А.И. Эколого-флористическая классификация лесов Южного Нечерноземья России. Брянск, 2003. 359 с. 
Betula pendula in addition to pine. Distributed on moderately moist soddyweakly podzolic soils.

5. Acc. Veronico incanae-Pinetum Bulokhov et Solomeshch 2003. Woody pine with a small admixture of Betula pendula. They are confined to clay-sandy gley soils. The herb-shrub layer is well developed.

\section{The main results of the analysis of phytopopulation stability}

Groups of plant species were identified in each of the associations, based on the occurrence and abundance, which are structure-forming of the herbdwarf shrub layer. The list of these types will be given in Table.1.

The analysis shows that the vast majority of species of structure-forming species in the considered forests are perennials. They are either hemicryptophytes, whose renewal buds are located at the soil level, or cryptophytes (geophytes) with buds below the soil level. These plant species account for $84 \%$ of the total flora of the grass-dwarf shrub layer (Fig. 1).

The plant species vital state of the grass-dwarf shrub layer was assessed in the form of vitality according to the method developed by Yu.A. Zlobin $(1989,2018)^{20}$. Vitality analysis is widely used by many researchers both individually and in a comprehensive assessment of the state of phytopopulations. This method is the most effective and accurate, since it is based not on eye assessments of the state of plants, but on their morphometric characteristics reflecting the development of vegetative and generative structures of plant individuals.

In the main algorithm of vitality analysis, based on the data of their morphometric analysis, species in the population are divided into three classes of vitality: "a", "b" and "c". For this, the range of species' vitality values is divided into three equal zones: the highest class of vitality - class "a", class "b", intermediate and class "c" - individuals of lower vitality. Population vitality type is calculated by the formula:

$$
\mathrm{Q}=1 / 2(\mathrm{a}+\mathrm{b}) \text {. }
$$

Depending on the value of $\mathrm{Q}$, the population belongs to one of three vitality types: prosperous, equilibrium or depressed.

20 Злобин Ю.А. Теория и практика оценки виталитетного состава популяций растений. Ботанический журнал. 1989. Т. 74. № 6. С. 769-781. 
Plant species of the herb-dwarf shrub structure-forming layer

\begin{tabular}{|c|c|}
\hline Associations & $\begin{array}{c}\text { Structure formers types } \\
\text { of the grass-dwarf shrub layer }\end{array}$ \\
\hline $\begin{array}{l}\text { Mercuriali perrenis-Quercetum roboris } \\
\text { Bulokhov et Solomeshch } 2003\end{array}$ & $\begin{array}{l}\text { Aegopodium podagraria } \\
\text { Carex pilosa } \\
\text { Convallaria majalis } \\
\text { Dryopteris carthusiana } \\
\text { Majanthemum bifolium } \\
\text { Rubus saxatilis } \\
\text { Stellaria holostea }\end{array}$ \\
\hline $\begin{array}{l}\text { Querco robori-Pinetum (W. Matusz- } \\
\text { kiewicz 1981) J. Matuszkiewicz } 1988\end{array}$ & $\begin{array}{l}\text { Anemone nemorosa } \\
\text { Calamagrostis arundinacea } \\
\text { Carex digitata } \\
\text { Majanthemum bifolium } \\
\text { Melica nutans } \\
\text { Oxalis acetosella } \\
\text { Pteridium aquilinum } \\
\text { Veronica chamaedrys }\end{array}$ \\
\hline $\begin{array}{l}\text { Molinio-Pinetum W. Matuszkiewicz } \\
\text { et J. Matuszkiewicz (1973) } 1983\end{array}$ & $\begin{array}{l}\text { Molinia caerulea } \\
\text { Potentilla erecta } \\
\text { Vaccinium myrtillus } \\
\text { Vaccinium vitis-idaea } \\
\text { Melampyrum pratense }\end{array}$ \\
\hline $\begin{array}{l}\text { Peucedano-Pinetum W. Matuszkie-wicz } \\
\text { (1962) } 1973\end{array}$ & $\begin{array}{l}\text { Calamagrostis arundinacea } \\
\text { Carex ericetorum } \\
\text { Convallaria majalis } \\
\text { Polygonatum odoratum } \\
\text { Trientalis europaea } \\
\text { Solidago virgaurea }\end{array}$ \\
\hline $\begin{array}{l}\text { Veronico incanae-Pinetum Bulokhov } \\
\text { et Solomeshch } 2003\end{array}$ & $\begin{array}{l}\text { Veronica incana } \\
\text { Rubus saxatilis } \\
\text { Polygonatum odoratum } \\
\text { Orthilia secunda } \\
\text { Peucedanum oreoselinum } \\
\text { Hieracium umbellatum } \\
\text { Calluna vulgaris } \\
\text { Luzula pilosa }\end{array}$ \\
\hline
\end{tabular}




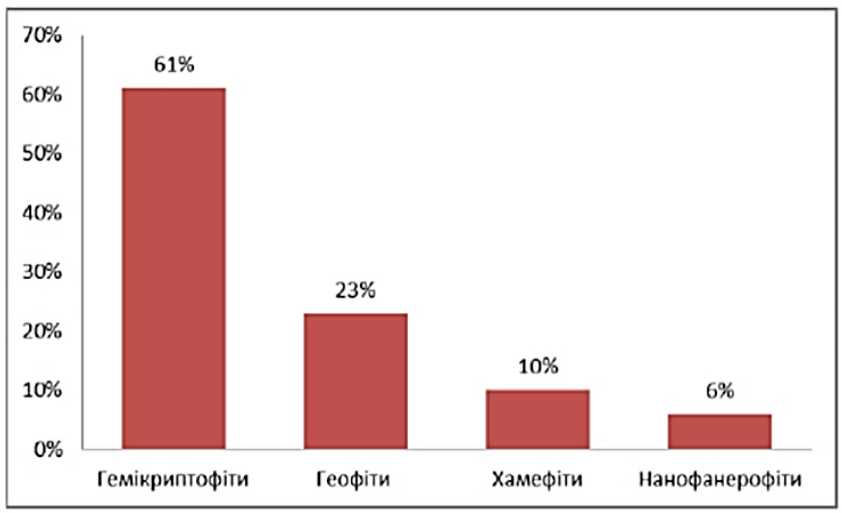

Figure 1. The ratio of different life forms plants in forest phytocenoses of the Ukrainian Polesie

The assessment of the species vitality and the vital structure of populations was carried out for 15 structure-forming species - three species from each association. The results are presented in Table. 2.

It was found that phytopopulations of structure-forming plant species of the herb-dwarf shrub layer in the studied associations of forest phytocenoses have vitality index $\mathrm{Q}$ values ranging from 0,204 to 0,488 , and the vitality type of the population varies from prosperous to equilibrium. Populations of depressive vitality type among structure-forming plant species have not been registered. In general, the data obtained indicate the stability of plant phytopopulations, which form the basis of the herb-shrub layer in forest phytocenoses.

The considered group of associations is dominated by vegetatively mobile plants in the group of structure-forming plant species. In the forest communities of the Ukrainian Polesie, as was shown earlier, such species are retained in the grass-dwarf shrub layer most steadily under various adverse effects on phytocenoses due to the ability to form clones ${ }^{21}$.

${ }^{21}$ Коваленко I.М. Екологія рослин нижніх ярусів лісових екосистем. Суми, 2015. 360 c. 
Table 2

Vitality of species and vitality populations' structure of structure-

forming plant species of the herb-dwarf shrub layer

\begin{tabular}{|c|c|c|}
\hline Plant species & Vitality index, $Q$ & Population vitality type \\
\hline \multicolumn{3}{|c|}{ Acc. Mercuriali perrenis-Quercetum roboris } \\
\hline Aegopodium podagraria & 0,401 & Prosperous \\
\hline Carex pilosa & 0,239 & Equilibrium \\
\hline Stellaria holostea & 0,235 & Equilibrium \\
\hline \multicolumn{3}{|c|}{ Acc. Querco robori-Pinetum } \\
\hline Calamagrostis arundinacea & 0,390 & Prosperous \\
\hline Majanthemum bifolium & 0,417 & Prosperous \\
\hline Veronica chamaedrys & 0,204 & Equilibrium \\
\hline \multicolumn{3}{|c|}{ Acc. Molinio-Pinetum } \\
\hline Molinia caerulea & 0,451 & Prosperous \\
\hline Vaccinium myrtillus & 0,377 & Prosperous \\
\hline Vaccinium vitis-idaea & 0,252 & Equilibrium \\
\hline \multicolumn{3}{|c|}{ Acc. Peucedano-Pinetum } \\
\hline Carex ericetorum & 0,351 & Prosperous \\
\hline Polygonatum odoratum & 0,405 & Prosperous \\
\hline Trientalis europaea & 0,397 & Prosperous \\
\hline \multicolumn{3}{|c|}{ Acc. Veronico incanae-Pinetum } \\
\hline Calluna vulgaris & 0,244 & Equilibrium \\
\hline Rubus saxatilis & 0,488 & Prosperous \\
\hline Orthilia secunda & 0,366 & Prosperous \\
\hline
\end{tabular}

Combination generative and vegetative reproduction in the conditions of the sub-forest space gives them an advantage in the implementation of the reproductive cycle and increases the stability of phytopopulations.

A detailed study of typical species generative reproduction of structureforming plants has shown that their generative potential is also at a fairly high level.

In Aegopodium podagraria, the mass of the generative organs varied from 0,7 to $1,5 \mathrm{~g}$. The values of reproductive effort were $10.9-15.8 \%$.

The reproduction feature of Carex pilosa was the low mass of generative structures: $0.12-0.15 \mathrm{~g}$, but the proportion of generative shrubs in the population was $38.8-62.4 \%$. Reproductive effort was equal to $9.8-7.5 \%$.

The share of Calluna vulgaris generative partial shrubs in the studied forest associations was 15.1-67.4\%. The number of generative shoots per species ranged from 7.2 to 12.8 pcs. Reproductive effort was $1.8-2.8 \%$.

The number of generative plants in the populations of Molinia caerulea was at the level of $11-20 \%$. The weight of the generative structures was 1.2-1.4 g. The reproductive effort was high: $34.0-41.7 \%$. 
The number of generative partial shrubs of Stellaria holostea was $19-33 \%$. Reproductive effort was $22.9-32.7 \%$.

The proportion of generative partial shrubs of Vaccinium myrtillus in different associations varied from 46 to $88 \%$. The average fruit yield was 3.3-92.6 g / $\mathrm{m}^{2}$, varying greatly by association and year. Reproductive effort was also variable and ranged from 5.4 to $54.4 \%$.

The reproductive effort of Vaccinium vitis-idaea was also high, 13.6 to $24.4 \%$, with a total phytomass of generative structures up to $20.8 \mathrm{~g} /$ species.

In general, generative reproduction in structure-forming plant species was at a sufficiently high level and provided them with a high reproductive potential in combination with vegetative reproduction.

The stability of phytopopulations in forests is, to a certain extent, due to the ability of species to change their ontogenetic state in the process of growth and development. T.A. Rabotnov (1950), on the basis of the correlation of species different ontogenetic states in plant populations, divided the populations into three groups: invasive - penetrating into the phytocenosis, normal - passing through the full life cycle in the phytocenosis and stably existing in it and depressed ones - falling out of the phytocenosis. In normal populations, pre-generative and generative plants predominate. In invasive populations, pre-generative individuals predominate, and in depressive ones, subsenile and senile states. The main condition for the species populations' stability is the fullness of the age structure $^{22}$.

Variations in ontogenetic spectra of populations are due to the conditions in which plant ontogenesis takes place. Therefore, ontogenetic spectra of populations carry important information about the course of the species renewal and death processes, as well as the rate of generational change and, therefore, allow one to evaluate and predict the dynamic processes in phytocenoses that are formed by these populations.

Ontogenetic spectra of plant populations are of independent importance, they almost do not correlate with the population density and the number of plants in it.

In the studied plant associations of forest phytocenoses, the ontogenetic spectra of structure-forming plant species are rather similar. This is illustrated by the ontogenetic spectra of four of the studied plant species (Fig. 2). They are all incomplete:

${ }^{22}$ Работнов Т.А. Вопросы изучения состава популяций для целей фитоценологии. Проблемы ботаники. Москва ; Ленинград : Наука, 1950. С. 465-483. 


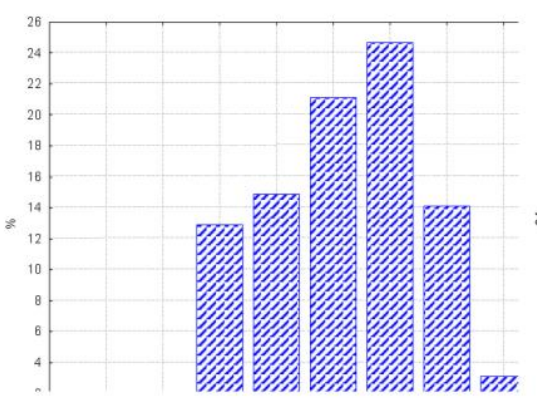

Aegopodium podagraria

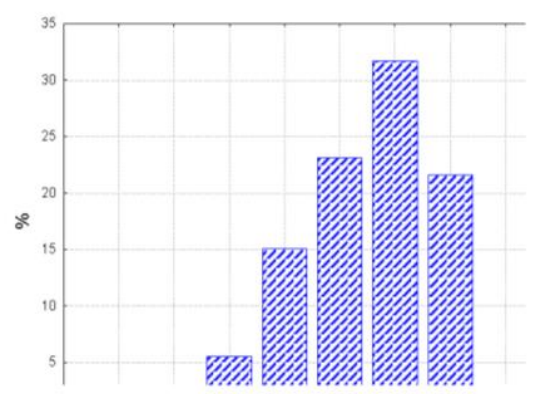

Molinia caerulea

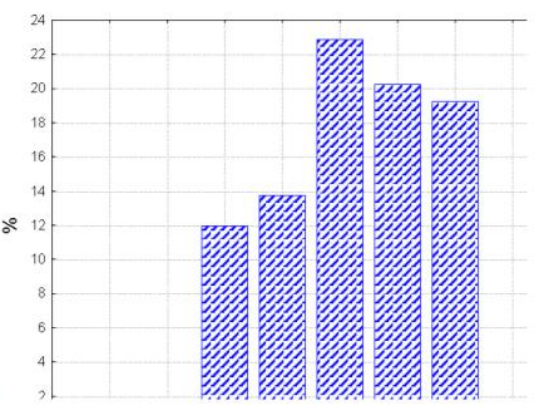

Carex pilosa

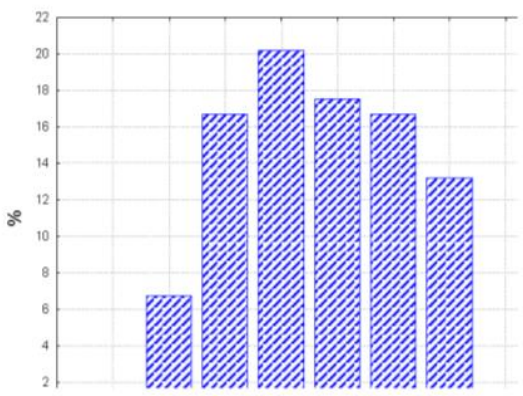

Vaccinium myrtillus

Figure 2. Typical ontogenetic spectra of structure-forming plant species of the herb-dwarf shrub cover

by the middle of summer, when the counts were carried out, the phytopopulations usually lack seedlings and sometimes juveniles. In most cases, subsenile plants are also absent in the populations. The most abundant are generative plants. This indicates that the ecological-phytocenotic environment is quite favorable for structure-forming species in the herbdwarf shrub layer of the studied forest associations of the Ukrainian Polesie. Indeed, plant species that are included in the forest phytocenosis are represented in it by local populations specific to this phytocenosis.

Many schemes and models have been proposed to explain the relationships between plants and their sustainable existence in phytocenoses. It is usually believed that the factor that determines the stability of forest phytocenoses is the ecological differentiation of the plant species that fold 
them $^{23}$. It is expressed in the difference between the positions of the ecological optimum and the width of ecological amplitudes and softens the competition between plant species of the same phytocenosis. But on the basis of theoretical considerations A.M. Gilyarov (2002), considering lottery models of phytocenoses, came to the conclusion that "the condition for the long-term coexistence of competing species is not the difference in their niches, but the similarity" 24 .

The analysis of the ecological properties of structure-forming plant species in the considered five associations of the Ukrainian Polesie showed that these species are more characterized by similarity, rather than the difference in ecological optimum and amplitudes.

As an example, the table 3 shows the ecological amplitudes of the structure-forming plant species of the Querco robori-Pinetum association according to three leading ecological factors: water regime and nitrogen content in the soil and illumination.

Indeed, the ecological amplitudes of the structure-forming plant species in this association, as well as the four others, are to a significant extent close and overlap. So, according to the factor soil moisture, the ecological optimum is between the 7th and 17th points of the scale, according to the nitrogen content in the soil - in the amplitude of 1-11 points of the scale, and in terms of illumination in the amplitude of 1-9. Even with some differences in the width of ecological niches, the ecological optima of the structureforming plant species of the Querco robori-Pinetum association, as in other associations, are brought together.

Table 3

\section{Ecological amplitudes of structure-forming plants of the Querco robori-Pinetum association}

\begin{tabular}{|c|c|c|c|}
\hline \multirow{2}{*}{ Plant species } & \multicolumn{3}{|c|}{ Environmental factors } \\
\cline { 2 - 4 } & Soil water regime & Nitrogen content & Illuminance \\
\hline Anemone nemorosa & $8-17$ & $3-11$ & $3-8$ \\
\hline Calamagrostis arundinacea & $8-16$ & $3-7$ & $5-7$ \\
\hline Carex digitata & $9-15$ & $2-7$ & $2-6$ \\
\hline Majanthemum bifolium & $8-16$ & $1-7$ & $3-6$ \\
\hline Melica nutans & $8-15$ & $2-7$ & $2-6$ \\
\hline Oxalis acetosella & $8-16$ & $5-10$ & $1-5$ \\
\hline Pteridium aquilinum & $8-14$ & $3-7$ & $5-8$ \\
\hline Veronica chamaedrys & $7-15$ & $3-8$ & $6-9$ \\
\hline
\end{tabular}

${ }^{23}$ Turcotte M., Levine J.M. (2016). Phenotypic plasticity and species coexistence. Trends in ecology and evolution. Vol. 31. № 10. P. 803-813.

${ }^{24}$ Гиляров А.М. Виды сосуществуют в одной экологической нише. Природа. 2002. № 11. C. 71-74. 
In relation to soil moisture, the ecological optimum of the considered group of plant species is within 11-12.5 points of the scale, in terms of nitrogen content - 4-7.5, illumination - 3-7.5. Thus, the structure-formers of the herb-dwarf shrub layer are characterized by the proximity of ecological requirements to the habitat. The mechanism of ecological differentiation, in contrast, works in relation to the assektators types.

When interpreting the ecological amplitudes of forest plants, one should not assume that the ecological amplitudes are constant and always the same as they are given in ecological scales. In fact, as shown on a large amount of material (Seledets, 2006), under conditions of a general ecological optimum, ecological amplitudes for each individual ecological factor are wider, and as they deviate from the general optimum, they become narrower ${ }^{25}$.

The stability of the forest phytocenosis is determined, along with other mechanisms, by the coadaptation of species of the herb-dwarf shrub layer with joint growth with the formation of groups of plants that create phytocenotic isolation. In biogeocenology, parcels and synusia are distinguished as such structures. In phytocenology, the allocation of cenocells, the concept of which was developed by V.S. Ipatov (1966). A cenocell is a group of directly interacting plants. From such a group, the "strong species" displaces the "weak species" from the phytocenosis ${ }^{26}$. The cenocells are identified based on the study of the association of plant species in the phytocenosis.

The TDK index was used to calculate the association of species and to construct the cenocells models formed by the structure-formers of the grassdwarf shrub layer (Mirkin, 2012):

$$
A=\frac{a-b-c}{a+b+c}
$$

where $\mathrm{a}, \mathrm{b}$ and $\mathrm{c}$ are generally accepted notation for four-field tables.

The statistical significance of the index was assessed by the $\chi^{2}$ method according to Whittaker (Whittaker, 1970):

$$
\chi^{2}=\frac{[(a d-b c)-0,5 N]^{2} \cdot N}{(a+b)(a+c)(b+d)(c+d)}
$$

Only statistically significant indices were used at $\mathrm{p}<0.05$ for meaningful analysis

25 Селедец В.П. Экологические ареалы видов растений на тихоокеанском побережье России в сравнении с внутриконтинентальными регионами. Комаровские чтения. 2006. Вып. LIII. C. 54-100.

${ }^{26}$ Koddy P.A. Competitive hierarchies and centrifugal organization plant communities. Perspective in plant competition. San-Diego, 1990. P. 265-289. 
As an illustration, Fig. 3 shows a model of a cenocell dominating in the herb-shrub layer of the species Molinia caerulea in the Molinio-Pinetum association. It turned out that the main components of the cenocell were the codominants of Molinia caerulea: Dryopteris carthusiana, Potentilla erecta, Vaccinium vitis-idaea, Vaccinium myrtillus, and Majanthenum bifolium. The assektators species of the studied forest type with a low frequency and low abundance of Aegopodium podagraria, Asarum aeropaeum, and Poa pratensis have a statistically significant negative association with the systemforming species of this cenocell.

Both in this model and in models for other studied plant species of the herb-dwarf shrub layer, cenocells form, in the overwhelming majority of cases, structure-forming plant species. These species are positively associated with each other within a particular association. In contrast, the assektators species are associated with structure-forming species by negative association coefficients. Sometimes the association coefficients between these species are 0,0 .

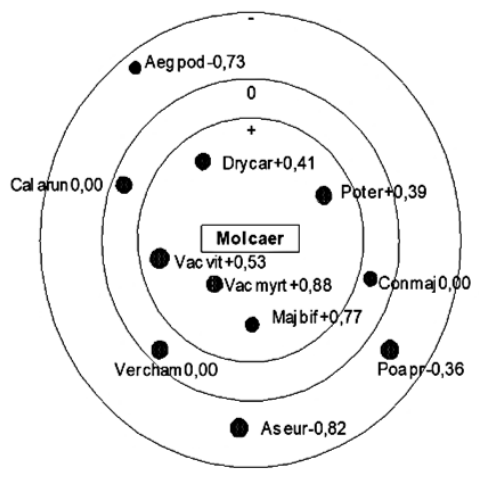

Figure 3. Model of the Molinia caerulea cenocell in the Molinio-Pinetum association

Species designations Mol caer - Molinia caerulea, Aeg pod Aegopodium podagraria, Ver cham - Veronica chamaedris, Cal arun Calamagrostis arundinacea, Poter - Potentilla erecta, Vac vit - Vaccinium vitis-idaeum, Vac myr - Vaccinium my Asrtillus aeropaeum, Poa pr - Poa pratensis, Con maj - Convallaria majalis, Dry car - Dryopteris carthusiana, Pot er - Potentilla erecta, Maj bif - Majanthenum bifolium. 


\section{CONCLUSIONS}

Forest phytocenoses are multi-tiered formations. The main key mechanisms that ensure the sustainability of forests are implemented in their grass-shrub layer, which is associated with the germination of seeds of forest-forming tree species, the survival of their seedlings and small undergrowth. In turn, the preservation of the integrity and stability of the herb-dwarf shrub layer is due to the peculiarities of the phytopopulations of the plants that structure this layer. The conditions for the stability of the forest phytocenosis are a high level of viability of plant species forming the herb-dwarf shrub layer, the success of their reproduction, full-member phytopopulations according to ontogenetic composition and the organization of plant cenocells, structure-forming plants of the herb-dwarf shrub layer.

The functioning of mechanisms to ensure the forest phytocenoses sustainability at the level of populations of the herb-dwarf shrub layer plays an important role, but no less important is the correct organization of forestry in Ukraine. The set of new principles and methods that should ensure the environmentally sustainable existence of forests and prevent their further degradation has received different names from different authors: "environmentally oriented forestry", "environmental forestry", "forestry close to nature", "biosphere-compatible use of forest resources", "sustainable forest management". The transition of forest management to the principles of environmentally oriented forestry envisaged the full ban on concentrated final felling. This allows preserving the biodiversity of forest ecosystems and, from an ecological point of view, transfers the process of reforestation to a natural path and protects forests from fragmentation.

\section{SUMMARY}

Therefore, the obtained data indicate that the formation of cenocells as groups of species with positive associative connections acts as one of the mechanisms of the stability of the herb-shrub layer and the stability of the forest phytocenosis in general. It is the mechanism of the formation of closed cenocells, along with other mechanisms considered above, that contributes to the integrity and sustainability of the forests of Ukrainian Polessye.

\section{REFERENCES}

1. Андрієнко Т.Л. Рослинність Українського Полісся. Фіторізноманіття Украӥнського Полісся та його охорона. Київ, 2006. C. 13-37. 
2. Бех И.А., Данченко А.М. Проблема устойчивости в лесоведении. Вестник Томского государственного университета. 2007. № 295. C. 215-219.

3. Брадіс Є.М., Андрієнко Т.Л. Детальне геоботанічне районування Полісся УРСР. Украӥнський ботанічний журнал. 1975. Т. 32. № 4. C. 471-475.

4. Булохов А.Д., Соломещ А.И. Эколого-флористическая классификация лесов Южного Нечерноземья России. Брянск, 2003. 359 с.

5. Вахрушев А.А., Раутиан А.С. Исторический подход в экологии: сущность и перспективы. Биологическое разнообразие: подходы $к$ изучению и сохранению : мат. конф. БИН РАН и ЗИН РАН. 1992. С. 14-15.

6. Гиляров А.М. Виды сосуществуют в одной экологической нише. Природа. 2002. № 11. С. 71-74.

7. Дыренков С.А. Структура и динамика таежных ельников. Львов : Наука, 1984. $174 \mathrm{c}$.

8. Демаков Ю.П. Диагностика устойчивости лесных экосистем: методологические и методические аспекты. Йошкар-Ола, 2000. 416 с.

9. Злобин Ю.А. Теория и практика оценки виталитетного состава популяций растений. Ботанический журнал. 1989. Т. 74. № 6. C. $769-781$.

10. Коваленко И.Н. Биоразнообразие растений нижних ярусов лесных экосистем как предпосылка их устойчивости. Вестник КГУ им. Некрасова. 2014. № 4. С. 41-44.

11. Коваленко I.M. Екологія рослин нижніх ярусів лісових екосистем. Суми, 2015. 360 c.

12. Лукаш А.В., Андриенко Т.Л. Созологически ценные растительные сообщества Полесья. Чернигов, 2014. 160 с.

13. Панченко С.М., Кутявін Є.Г. Гербарій Національного природного парку «Деснянсько-Старогутський». Суми : Унів. книга, 2011. $82 \mathrm{c}$.

14. Природообустройство Полесья : монография / под общ. науч. ред. Ю.А. Мажайского и др. Рязань : Мещер. ф-л ВНИИГиМ им. А.Н. Костякова, 2018. Кн. 2. Т. 2.804 с.

14. Работнов Т.А. Вопросы изучения состава популяций для целей фитоценологии. Проблемы ботаники. Москва ; Ленинград : Наука, 1950. С. 465-483.

15. Реймерс Н.Ф. Экология (теории, законы, правила, принципы и гипотезы). Москва : Россия Молодая, 1994. 367 с.

16. Романовский М.Г., Тарханов С.Н., Щекалев Р.В. Подходы к описанию биоразнообразия равнинных лесов Европейской России. Лесной журнал. 2009. № 4. С. 47-56. 
17. Сірук Ю.В., Печенюк Є.П., Чернюк Т.М. Типологічна структура та характеристика лісового фонду центрального Полісся України. Науковий вісник НЛТУ Украӥни. 2015. Вип. 25.10. С. 97-103.

18. Состояние лесов мира - 2020. Леса, биоразнообразие, люди. Рим : ФАО. URL: https://doi.org/10.4060/ca8642ru.

19. Стойко С.М. Основи фітосозології та ії завдання у збереженні фітогенофонду і фітоценофонду. Украӥнський ботанічний журнал. 2011. T. 68. № 3. C. 331-351.

20. Скляр В.Г. Ценотичні зв'зки підросту клена гостролистного та дуба звичайного в умовах Новгород-Сіверського Полісся. Біологічний вісник МДПУ. 2012. № 3. С. 77-88.

21. Селедец В.П. Экологические ареалы видов растений на тихоокеанском побережье России в сравнении с внутриконтинентальными регіонами. Комаровские чтения. 2006. Вып. LIII. C. 54-100.

22. Weiher E., Keddy P. Assembly rules as general constraints on community composition. Ecological assembly rules: perspectives, advances, retreats. 2004. P. 251-271.

23. Matuszkiewicz W. Przewodnik do oznaczania zbiorowisk roślinnych Polski. Warczawa, 2001. 537 p.

24. Turcotte M., Levine J.M. (2016). Phenotypic plasticity and species coexistence. Trends in ecology and evolution. Vol. 31. № 10. P. 803-813.

25. Koddy P.A. Competitive hierarchies and centrifugal organization plant commu-nities. Perspective in plant competition. San-Diego, 1990. P. 265-289.

\section{Information about the author:} Kovalenko I. N.,

Doctor of Biological Sciences, Professor, Dean of the Faculty of Agrotechnologies and Natural Resource Management Sumy National Agrarian University 160/5, H. Kondratieva str., Sumy, 40021, Ukraine 